\title{
PENGARUH Nigella sativa TERHADAP JUMLAH NEUTROFIL DAN PERBAIKAN SCORING ASTHMA CONTROL TEST PADA ANAK ASMA
}

\author{
Vivin Detriana* ${ }^{* \varpi}$, Wisnu Barlianto**, HMS Chandra Kusuma*
}

\begin{abstract}
Abstrak
Asma merupakan gangguan inflamasi kronik saluran napas. Sebagian besar kasus asma dipengaruhi oleh peningkatan neutrofil jalan nafas. Penderita asma yang tidak terkontrol memberikan dampak negatif. Alat atau metode tervalidasi untuk menilai kontrol klinis asma yaitu Asthma Control Test/ACT. Saat ini berkembang pengobatan asma dengan menggunakan immunomodulator Nigella sativa (NS). Penelitian ini ingin mengetahui pengaruh pemberian NS terhadap jumlah neutrofil dan scoring ACT pada kelompok anak asma ringan sedang. Penelitian ini berjenis eksperimental, clinical trial, pre-post control study untuk scoring asma. Populasi penelitian adalah semua anak yang didiagnosis asma ringan dan sedang yang memenuhi kriteria, di Poli Respirologi Anak dan Alergi Imunologi Anak RS. Dr. Saiful Anwar Malang selama periode Januari-September 2016, jumlah sampel 28 pasien yang dibagi menjadi kelompok A (asma ringan+NS), B (asma sedang+NS), C (kontrol asma ringan), D (kontrol asma sedang), masing-masimg kelompok dilakukan pemeriksaan darah lengkap dan peilaian skor ACT pre-post selang 8 minggu. Berdasarkan hasil analisis statistik didapatkan penurunan yang tidak signifikan jumlah neutrofil setelah perlakuan pada kelompok A (asma ringan dengan pemberian NS) ( $p=0,359)$, didapatkan peningkatan signifikan skor ACT setelah perlakuan pada semua kelompok, dan didapatkan korelasi negatif signifikan antara jumlah neutrofil dan skor ACT pada kelompok asma sedang sebelum perlakuan $(p=0,015)$. Kesimpulannya, pemberian Nigella sativa pada anak asma ringan dan sedang, tidak dapat menurunkan neutrofil. Pemberian Nigella sativa pada anak asma ringan dan sedang dapat meningkatkan skor ACT. Tidak terdapat hubungan antara penurunan neutrofil dan peningkatan skor ACT setelah pemberian Nigella sativa pada anak asma ringan dan sedang.
\end{abstract}

Kata kunci: anak, asma, neutrofil, Nigella sativa, skor ACT.

\section{EFFECT OF THE Nigella Sativa ON NEUTROPHIL LEVELS AND IMPROVEMENT OF SCOR- ING ASTHMA CONTROL TEST IN ASTHMA CHILDREN}

\begin{abstract}
Asthma is a complex chronic inflammatory airway disorder. Most cases of asthma are affected by increased airway neutrophils. In people with uncontrolled asthma, it will have a negative impact. Validated tool or method for assessing clinical control of asthma, namely Asthma Control Test/ACT. Currently, developing the treatment of asthma using Nigella sativa immunomodulators. This research aims to determine the effect of NS administration on neutrophil counts and ACT scoring in mild to moderate asthma children. The result showed that there was no significant decrease in neutrophil levels after treatment in the mild asthma treatment group with the administration of Nigella sativa $(p=0.359$ ), there was a significant increase in ACT scores after treatment in all groups, and ACT scores in the moderate asthma group before the treatment $(p=0.015)$. In conclusion, the administration of Nigella sativa in mild and moderate asthma children cannot reduce neutrophils. Giving Nigella sativa in mild and moderate asthma children can increase ACT scores. There was no relationship between a decrease in neutrophils and an increase in ACT scores after the administration of Nigella sativa in mild and moderate asthma children.
\end{abstract}

Keywords: ACT scores, asthma, children, neutrophils, Nigella sativa.

*Program Studi Magister IImu Biomedik, Fakultas Kedokteran, Universitas Brawijaya

${ }^{* *}$ Departemen IImu Kesehatan Anak, Fakultas Kedokteran, Universitas Brawijaya-RS. Dr. Saiful Anwar Malang

E-mail: vivindetrianadr@gmail.com 


\section{Pendahuluan}

Asma merupakan salah satu penyakit kronik yang tersebar di seluruh belahan dunia dan sejak 20 tahun terakhir prevalensinya semakin meningkat pada anak-anak baik di negara maju maupun negara sedang berkembang. Asma merupakan penyakit heterogen, biasanya ditandai dengan inflamasi kronis pada saluran napas. ${ }^{1}$

Banyak tipe sel yang berperan pada patofisiologi asma, salah satu sel yang berperan adalah limfosit T. Selain sel limfosit, ternyata sel neutrofil juga ikut berperan dalam timbulnya asma pada anak. Neutrofil merupakan sel yang cepat bereaksi terhadap radang dibandingkan dengan leukosit lain, sehingga merupakan garis depan pertahanan selama fase peradangan dan infeksi akut, dan merupakan sel radang pertama kali yang datang ke tempat terjadinya reaksi alergi..2,3

Tujuan tatalaksana asma anak secara umum adalah mencapai kendali asma sehingga menjamin tercapainya potensi tumbuh kembang anak secara optimal. ${ }^{5}$ Secara klinis, keberhasilan kontrol gejala asma dapat dinilai dengan sistem scoring. Salah satu sistem scoring asma anak yang telah tervalidasi adalah asthma control test (ACT). ${ }^{6}$

Saat ini, berkembang pengobatan asma dengan pengobatan menggunakan immunomodulator. Salah satu imunomodulator alami yang banyak diteliti untuk penyakit alergi adalah Nigella sativa. Selain berpotensi sebagai imunomodulator, Nigella sativa memiliki efek antiinflamasi yang bermanfaat pada asma. ${ }^{7,8}$

Pada penelitian yang dilakukan oleh Ramadheni (2014), mengenai pengaruh pemberian Nigella sativa peoral terhadap nilai hitung jenis sel pada pasien asma, terlihat bahwa terdapat perbedaan bermakna antara nilai sel neutrofil batang pada awal dan akhir penelitin pada seluruh kelompok usia baik pada kelompok kontrol maupun kelompok perlakuan. ${ }^{9}$

Pada anak asma ringan yang diberikan Nigella sativa dan imunoterapi serta probiotik, pada penelitian Muhyi et al tahun 2015, didapatkan hasil Asthma Control Test secara bermakna didapatkan perbedaan antara perlakuan imunoterapi plus probiotik dibandingkan imunoterapi saja, dan terjadi penurunan kadar Th17 meskipun tidak diikuti penurunan kadar neutrophil. ${ }^{10}$

Berdasarkan peneltian yang telah ada sebelumnya, maka peneliti akan mengamati peningkatan jumlah neutrofil pada penderita asma anak ringan dan asma sedang (hanya mendapat terapi standar asma tanpa mendapat imunoterapi) dan dengan memberikan perlakuan pemberian peroral Nigella sativa yang bertujuan untuk mengetahui pengaruhnya terhadap jumlah neutrofil dan mengetahui adanya perbaikan klinis asma. Studi ini mengkaji bagaimana pengaruh pemberian Nigella sativa terhadap jumlah neutrofil pada pasien asma anak ringan sedang dan perbaikan scoring Asthma Control Test.

\section{Bahan dan Metode}

Penelitian ini merupakan penelitian eksperimental, clinical trial, pre-post control study untuk scoring asma. Populasi penelitian ini adalah semua anak yang didiagnosis asma serta memenuhi kriteria inklusi dan eksklusi di Poli Respirologi Anak dan Poli AlergiImunologi Anak RS. Dr. Saiful Anwar Malang, pada bulan Januari-September 2016.

Subjek adalah pasien asma ringan dan sedang. Teknik pengambilan subjek penelitian dengan metode consecutive sampling kemudian dilakukan randomisasi, dengan total subjek sebanyak 28 anak. Subjek dibagi menjadi 4 kelompok, dengan perlakuan pada kelompok A (asma ringan, mendapat terapi standar short acting beta agonis, kortikosteroid inhalasi dosis rendah dan Nigella sativa) 
dan kelompok B (asma sedang, mendapat terapi standar long acting beta agonis, kortikosteroid inhalasi dosis rendah dan Nigella sativa), kelompok kontrol pada kelompok $C$ (asma ri-ngan, hanya mendapat terapi standart short acting beta agonis, kortikosteroid inhalasi dosis rendah) dan kelompok $D$ (asma sedang, hanya mendapat terapi standar long acting beta agonis, kortikosteroid inhalasi dosis ren-dah) tidak diberikan Nigella sativa. Seluruh perlakuan diberikan selama 8 minggu. Kriteria inklusi yaitu anak yang didiagnosis asma ri-ngan dan sedang berdasarkan GINA (Global Initiative for Athma) 2016, berusia antara 5-14 tahun, pasien dan orang tua pasien bersedia secara sukarela mengikuti penelitian dan menandatangani informed consent.

Kriteria eksklusi yaitu pasien yang menderita imunodefisiensi, penyakit autoimun atau memiliki kelainan kardiovaskular, pasien menderita komorbid atau penyakit saluran pernafasan lain seperti sinusitis, pneumonia, tuberkulosis dan kelainan anatomi seperti polip hidung, pasien memiliki riwayat alergi berat seperti syok anafilaksis dan asma serangan berat yang mengancam jiwa (lifethreatening asthma), memiliki riwayat gagal napas atau pernah diintubasi dalam 6 bulan terakhir. Kriteria drop out yaitu tidak minum Nigella sativa sesuai yang direkomendasikan peneliti, memenuhi kriteria eksklusi selama pengamatan penelitian, mengalami efek samping yang berat seperti syok anafilaktik, dan orang tua atau anak ingin berhenti.

Variabel tergantung pada penelitian ini adalah jumlah neutrofil dan skor ACT. Definisi operasional jumlah neutrofil pada studi ini adalah jumlah neutrofil yang dihitung di dalam darah dengan satuan \%. Nigella sativa (jinten hitam) yang digunakan adalah minyak jinten hitam dalam kapsul lunak, diberikan dengan dosis $600 \mathrm{mg}$ per hari (15-30 mg/kgBB/hari). ${ }^{11}$

Asthma Control Test merupakan salah satu metode tervalidasi yang dapat digunakan untuk menilai klisis asma anak. Sebelum dipergunakan, Asthma Control Test ini telah dilakukan uji validitas dan reabilitas, dengan menggunakan sampel pasien yang berbeda. Asma ringan adalah asma intermiten, asma persisten ringan dan asma sedang adalah asma persisten sedang. Untuk diagnosis asma pada anak usia lebih dari 5 tahun digunakan definisi asma berdasarkan GINA dan UKK Pulmonologi PP IDAI serta alur diagnosis asma yang ditetapkan oleh UKK Pulmonologi PP IDAI. ${ }^{5}$

Semua populasi penelitian dilakukan anamnesa, pemeriksaan fisik, pemeriksaan penunjang. Setiap subjek penelitian diambil data demografi, sejumlah 28 subjek penelitian dilakukan randomisasi menjadi 4 kelompok (masing-masing 7 subjek penelitian) dan diberikan perlakuan sesuai dengan kelompok masing-masing. Subjek dilakukan penilaian skor ACT dan pemeriksaan darah lengkap, setiap subjek penelitian diamati secara rutin setiap minggu selama 8 minggu tentang keluhan, gejala klinis, respons klinis penyakit, kepatuhan minum obat, penghindaran alergen dan kategori asma. Setelah perlakuan selama 8 minggu, subjek penelitian dilakukan penilaian skor ACT dan diambil sampel darah untuk pemeriksaan darah lengkap.

\section{Teknik Analisis Statistik}

Pada data jumlah neutrofil dan skor ACT sebelum dan setelah perlakuan dilakukan uji normalitas terlebih dahulu. Jika sebaran data normal dan varian data sama, maka digunakan uji ANOVA satu arah dan tes Post Hoc untuk mengetahui perbedaan jumlah neutrofil dan setelah perlakuan, beserta selisihnya, serta nilai ACT sebelum dan 
setelah perlakuan beserta selisihnya antar kelompok. Untuk membandingkan jumlah neutrofil dan skor ACT pada masing-masing kelompok dilakukan uji $t$ berpasangan membandingkan sebelum dan sesudah perlakuan, dan diolah menggunakan software statistical product and service solution 16 (SPSS 16).

\section{Hasil}

Sampel dalam penelitian ini adalah 28 anak yang terdiri atas pasien dengan asma ringan dan asma sedang dengan rentang usia 5-14 tahun yang menjalani rawat jalan di Poli Alergi dan Imunologi dan Poli Respirologi Anak Rumah Sakit Dr. Saiful Anwar Malang.

Karakteristik subjek pada keempat kelompok berjenis kelamin laki-laki dan perempuan dalam jumlah yang hampir sama. Namun, karakteristik responden berdasarkan umur diperoleh informasi bahwa rentang usia rata-rata 7-9 tahun .

Setelah syarat normalitas dan homogenitas ragam terpenuhi, selanjutnya dapat dilakukan analisis uji beda untuk mengetahui perbedaan jumlah neutrofil dan skor ACT pada masing-masing kelompok sebelum dan setelah perlakuan. Serta uji korelasi untuk melihat hubungan antara jumlah neutrofil dan skor ACT pada kelompok pasien asma yang mendapatkan terapi Nigella sativa.

Analisis perbandingan jumlah neutrofil sebelum perlakuan pada masing-masing kelompok ditampilkan pada Tabel 1. Berdasarkan Tabel 1 diketahui bahwa rata-rata jumlah neutrofil sebelum perlakuan menunjukkan nilai $p /$ sig uji $F=0,703$ yang lebih besar dari 0,05 . Oleh karena itu, disimpulkan bahwa tidak terdapat perbedaan bermakna jumlah neutrofil antar kelompok sebelum perlakuan.

Setelah diberi perlakuan yaitu pada kelompok $A$ dan $B$ selanjutnya dilakukan analisis uji Kruskal Wallis untuk melihat perbandingan jumlah neutrofil setelah perlakuan. Berdasarkan Tabel 2 diketahui bahwa rata-rata perbedaan jumlah neutrofil antar kelompok menunjukkan nilai $\mathrm{p} / \mathrm{sig}$ uji Kruskal wallis $=0,169$ yang lebih besar dari 0,05 . Oleh karena itu, disimpulkan bahwa tidak terdapat perbedaan jumlah neutrofil antar kelompok setelah perlakuan.

Tabel 3. Hasil uji t berpasangan jumlah neutrofil.

\begin{tabular}{cccc}
\hline \multicolumn{1}{c}{ Kelompok } & $\begin{array}{c}\text { Neutrofil } \\
\text { (sebelum perlakuan) }\end{array}$ & $\begin{array}{c}\text { Neutrofil } \\
\text { (setelah perlakuan) }\end{array}$ & Nilai $p$ \\
\hline Asma ringan + Nigella sativa (A) & $47,73 \pm 11,67$ & $42,81 \pm 9,72$ & 0,359 \\
Asma sedang + Nigella sativa (B) & $53,44 \pm 11,97$ & $54,07 \pm 9,12$ & 0,692 \\
Asma ringan (C) & $45,27 \pm 14,23$ & $48,67 \pm 14,39$ & 0,508 \\
Asma sedang (D) & $48,67 \pm 14,39$ & $55,43 \pm 4,75$ & 0,244 \\
\hline
\end{tabular}

Keterangan: Tidak terdapat perbedaan rerata jumlah neutrofil yang bermakna pada keempat kelompok asma, (nilai $p$ signifikan bila $<0,05$ ).

Tabel 4. Skor ACT sebelum perlakuan.

\begin{tabular}{lcc}
\hline \multicolumn{1}{c}{ Kelompok } & Skor ACT & Nilai $p$ \\
\hline Asma ringan + Nigella sativa (A) & $18 \pm 0,82^{\mathrm{b}}$ & \\
Asma sedang + Nigella sativa (B) & $15,14 \pm 2,91^{\mathrm{a}}$ & \\
Asma ringan (C) & $17,85 \pm 1,21^{\mathrm{b}}$ & 0,019 \\
Asma sedang (D) & $17,28 \pm 1,25 \mathrm{ab}$ & \\
\hline
\end{tabular}

Keterangan: Notasi yang berbeda menunjukkan terdapat perbedaan antar kelompok perlakuan dengan $\alpha$ $(0,05)$. 
Tabel 5. Rata-rata skor ACT setelah perlakuan.

\begin{tabular}{lcc}
\hline \multicolumn{1}{c}{ Kelompok } & Skor ACT & Nilai p \\
\hline Asma ringan + Nigella sativa (A) & $21 \pm 0,82^{\mathrm{b}}$ & \\
Asma sedang + Nigella sativa (B) & $19,42 \pm 2,30^{\mathrm{ab}}$ & \\
Asma ringan (C) & $20,71 \pm 0,76^{\mathrm{b}}$ & 0,009 \\
Asma sedang (D) & $18,57 \pm 0,97^{\mathrm{a}}$ & \\
\hline
\end{tabular}

Keterangan: Notasi yang berbeda menunjukkan terdapat perbedaan antar kelompok perlakuan dengan $\alpha$ $(0,05)$.

Tabel 6. Perbedaan skor ACT sebelum dan setelah perlakuan.

\begin{tabular}{lccc}
\hline \multicolumn{1}{c}{ Kelompok } & $\begin{array}{c}\text { Skor ACT } \\
\text { (Sebelum Perlakuan) }\end{array}$ & $\begin{array}{c}\text { Skor ACT } \\
\text { (Setelah Perlakuan) }\end{array}$ & Nilai p \\
\hline Asma ringan + Nigella sativa (A) & $18 \pm 0,82$ & $21 \pm 0,82$ & 0,001 \\
Asma sedang + Nigella sativa (B) & $15,14 \pm 2,91$ & $19,42 \pm 2,30$ & 0,001 \\
Asma ringan (C) & $17,85 \pm 1,21$ & $20,71 \pm 0,76$ & 0,004 \\
Asma sedang (D) & $17,28 \pm 1,25$ & $18,57 \pm 0,97$ & 0,004 \\
\hline
\end{tabular}

Keterangan: Terdapat perbedaan rerata skor ACT yang bermakna pada setiap kelompok (nilai p signifikan bila $<0,05)$.

\section{Pembahasan}

Pada penelitian ini terdapat empat kelompok yaitu kelompok (A) asma ringan terapi standar + Nigella sativa, (B) asma sedang terapi standar + Nigella sativa, (C) asma ringan terapi standar saja, dan (D) asma sedang terapi standar saja. Penderita diamati jumlah neutrofil yang merupakan indikator keparahan asma dan didapatkan rata-rata jumlah neutrofil yang tidak berbeda bermakna pada tiap kelompok asma, sebelum perlakuan dibandingkan setelah diberikan perlakuan selama 8 minggu. Pada kelompok A jumlah neutrofil sebelum dan setelah perlakuan mengalami penurunan, namun secara statistik besarnya penurunan dianggap tidak bermakna $(p>0,05)$.

Penurunan jumlah neutrofil sesuai hipotesis penelitian ini yang disebabkan pemberian Nigella sativa kemungkinan karena peningkatan produksi sel Treg yang dapat mensupresi respons imun inflamasi sel $\mathrm{T}$, yang kemudian menghambat Th17 yang berperan menginfiltrasi dan mengaktifasi granulosit neutrofil. 12,13 Penurunan neutrofil setelah pemberian Nigella sativa juga didapatkan pada penelitian Muhyi et al. (2015) terhadap pasien asma ringan dengan pemberian Nigella sativa, namun dikombinasi dengan imunoterapi fase rumatan dan probiotik dengan hasil penurunan dianggap tidak bermakna. ${ }^{10}$

Pada kedua kelompok kontrol mengalami peningkatan jumlah neutrofil, terutama pada kelompok kontrol asma sedang dengan nilai jumlah neutrofil sebelum dan sesudah pengamatan lebih tinggi. Hal ini bisa disebabkan pada kelompok kontrol masih terjadi inflamasi sistemik atau terjadi eksaserbasi asma yang dapat meningkatkan jumlah neutrofil. ${ }^{14}$

Tujuan jangka panjang terapi asma adalah pengendalian gejala dan mengurangi risiko. Skor ACT merupakan salah satu metode penilaian klinis asma dalam bentuk variabel numerik, skor $\leq 19$ memiliki makna klinis asma tidak terkontrol, sedangkan skor $>19$ bernilai klinis asma terkontrol baik. ${ }^{13}$ 
Hasil uji statistik penilaian skor ACT sebelum perlakuan, didapatkan nilai berbeda bermakna antara keempat kelompok. Hal ini menunjukkan bahwa sebelum perlakuan, semua subjek penelitian memiliki klinis asma berbeda antar kelompok. Hasil uji statistik skor ACT setelah perlakuan juga didapatkan nilai yang berbeda bermakna antara keempat kelompok. Terdapat perubahan bermakna skor ACT antara sebelum dan setelah perlakuan pada semua kelompok perlakuan. Pada kelompok (A) asma ringan terapi standar + Nigella sativa, (B) asma sedang terapi standar + Nigella sativa, dan (C) asma ringan terapi standar hasil rerata skor ACT setelah perlakuan $>19$. Sedangkan pada kelompok (D) asma sedang hanya dengan terapi standar, hasil rerata skor ACT setelah perlakuan masih $\leq 19$, meskipun diketahui terdapat perubahan secara bermakna dibanding sebelum perlakuan $(p=0,004)$. Hal ini juga menunjukkan bahwa pemberian Nigella sativa pada asma dengan terapi standar memiliki manfaat yang lebih baik dalam memperbaiki klinis anak asma dibandingkan dengan terapi standar saja. $15,16,17$

Dari hasil uji korelasi Pearson didapatkan hubungan negatif antara jumlah neutrofil dan skor ACT pada kelompok asma sedang dengan terapi standar. Koefisien korelasi menunjukkan korelasi negatif yang kuat $(r=-0,853)$, yang artinya semakin turun jumlah neutrofil maka akan diikuti peningkatan skor ACT. Korelasi antara jumlah neutrofil dan skor ACT memiliki nilai signifikansi 0,015 < 0,05 , sehingga memiliki hubungan yang bermakna pada asma sedang sebelum pengamatan, sedangkan pada asma ringan tidak dapatkan korelasi yang signifikan. Hal ini dikarenakan pada asma sedang dengan terapi standar, penderita mengalami episode gejala asma lebih dari 1 kali/minggu, namun tidak setiap hari. Asma sedang dapat dikontrol dengan 1-2 controller dan reliever yaitu kom- binasi steroid inhalasi dosis rendah-LABA, atau steroid inhalasi dosis menengah-SABA, atau steroid inhalasi dosis rendah dan pemberian LTRA + teofilin lepas lambat.6,18,19,20 Pada kelompok ini karena lebih dari 1 kali/ minggu mengalami eksaserbasi sehingga jumlah neutrofil yang tinggi saat awal pengamatan rerata $48,67 \pm 14,39$ dengan skor ACT rerata $17,28 \pm 1,25$.

Kelemahan pada penelitian ini antara lain tidak dilakukan pemeriksaan jumlah neutrofil pada broncho alveolar lavage (BAL), tidak digunakan plasebo untuk kelompok kontrol sehingga dapat mempengaruhi respons terapi pada penderita. Pada penelitian ini juga tidak dibedakan individu yang sedang mengalami serangan asma atau saat tidak mengalami serangan, sehingga dapat mempengaruhi jumlah neutrofil sebagai sel yang berperan pada saat terjadi infeksi akut. Adanya faktor risiko pada setiap sampel yang berbeda berupa paparan alergen, atopi, dan lingkungan yang sulit dikontrol oleh peneliti sehingga dapat terjadi eksaserbasi dan mempengaruhi hasil neutrofil saat akhir perlakuan. Perbedaan usia pada sampel mempengaruhi kepatuhan. Selain itu, jenis asupan nutrisi yang berbeda disebabkan faktor sosio-ekonomi pasien yang tidak sama. Penyesuaian dosis terapi standar yang diberikan dan kepatuhan konsumsi Nigella sativa di rumah yang tidak dapat diawasi dengan benar.

\section{Kesimpulan}

Pemberian Nigella sativa pada anak asma ringan dan sedang, tidak dapat menurunkan neutrofil. Pemberian Nigella sativa pada anak asma ringan dan sedang dapat meningkatkan skor ACT. Tidak terdapat hubungan antara penurunan neutrofil dan peningkatan skor ACT setelah pemberian Nigella sativa pada anak asma ringan dan sedang. 


\section{Kesimpulan}

Pemberian Nigella sativa pada anak asma ringan dan sedang, tidak dapat menurunkan neutrofil. Pemberian Nigella sativa pada anak asma ringan dan sedang dapat meningkatkan skor ACT. Tidak terdapat hubungan antara penurunan neutrofil dan peningkatan skor ACT setelah pemberian Nigella sativa pada anak asma ringan dan sedang.

\section{Daftar Pustaka}

1. Global Initiative for Asthma (GINA). Global Asthma Strategy of Management and Prevention. Cape Town: National Heart, Lung and Blood Institute. 2014.

2. Trifunovic J, Miller L, Debeljak Z, \& Horvat V. Pathologic Patterns of Interleukin 10 Expression-A Review. Biochemia Medica. 2015; 25(1):3648.

3. Monteseirín J, Bonilla I, Camacho MJ, Chacon P, Vega A, Chaparro A, Conde J, \& Sobrino F. Specific Allergens Enhance Elastase Release in Stimulated Neutrophils from Asthmatic Patients. Int Arch Allergy Immunol. 2009; 131:174-181.

4. Abbas AK \& Litchman AH. Cellular and Molecular Immunology. $8^{\text {th }}$ Edition. Boston: Saunders. 2015.

5. UKK Pulmonologi PP IDAI. Pedoman Nasional Asma Anak. Rahajoe N, Supriyatno $B$, Setyanto DB (Editor). Jakarta: IDAI. 2016. HIm. 1-15.

6. Global Initiative for Asthma (GINA). Global Initiative for Asthma: Global Strategy for Asthma Management and Prevention. GINA Executive Committee. 2016. P. 1-115.

7. Gholamnezhad Z, Keyhanmanesh R, \& Boskabady MH. Anti-inflammatory, Antioxidant, and Immunomodulatory Aspects of Nigella sativa for Its Preventive and Bronchodilatory Effects on Obstructive Respiratory Diseases: A Review of Basic and Clinical Evidence. Journal of Functional Foods. 2015; 17:910-927.

8. Ahmad A, Husain A, Mujeeb $M$, Khan SA, Najmi K, Siddique NA, Damanhouri ZA, \& Anwar F. A Review on Therapeutic Potential of Nigella sativa: A Miracle Herb. Asian Pac J Trop Biomed. 2013; 3 (5):337-353.

9. Ramadheni $P$, Wahyuni FS, Raveinal \& Khairsyaf $O$. The Effect of The Orally Given Black Caraway Seed's Formulation (Nigella sativa L.,) to Cell Counting Value to The Asthma Patients. Prosiding Seminar Nasional dan Workshop "Perkembangan Terkini Sains Farmasi dan Klinik IV". 2014.

10. Muhyi A., Barlianto W, Kusuma HMS C. Efek Pemberian Imunoterapi, Probiotik, Nigella sativa terhadap Th17, Neutrofil, dan Skoring Asma. Jurnal Kedokteran Brawijaya. 2015; 28(3).

11. Michel ML, Keller AC, Paget C, Fujio M, Tottein F, Savage PB, Wong $\mathrm{CH}$, Schneider E, Dy M, \& Leite-de-moraes, MC. Identification of an IL-17 Producing NK1.1 (neg) iNKT Cell Population Involved in Airway. J Exp Med. 2007; 204 (5):995-1001.

12. Simonian $\mathrm{PL}$, Wehrmann $\mathrm{F}$, Roark $\mathrm{CL}$, Born WK, Rebecca L, O'Brien \& Fontenot AP. Gammadelta T Cells Protect against Lung Fibrosis via IL-22. J Exp Med. 2010; 207(10):2239-2253.

13. Shi $Y$, Tatavoosian A, Aledia A \& Galant P. Cut Points for Asthma Control Tests in Mexican Children in Orange Country California. Ann Allergy Asthma Immunol. 2010; 109(1):108-113.

14. Coomes SM., Kannan Y, Pelly VS., Entwistle LJ, Guidi R, Perez-lioret J, Nikolov N, Muller W, \& Wilson MS. CD4+ Th2 Cells are Directly Regulated by IL10 during Allergic Airway Inflammation. 
15. Aziz AE, Sayed NS \& Mahran LG. AntiAsthmatic and Anti-Allergic Effects of Thymoquinone on Experimentally- Induced Hypersensitivity. Egyptian Journal of Basic and Clinical Pharmacology. 2011; 1(3):1-41.

16. Majdalawieh \& Fayyad. Immunomodulatory and Anti-Inflammatory Action of Nigella sativa and Thymoquinone: A Comprehensive Review. Int/mmunopharmacol. 2015; 28(1):295-304.

17. Paarakh PM. Nigella sativa A Comprehensive Review. Indian Journal of Natural Products and Resources. 2010; 1 (4):409-429.
18. Kartasasmita CB. Diagnosis dan Tata Laksana Terkini Asma pada Anak. Dalam: Bogor Pediatric Update. IDAI cabang Jawa Barat. 2015; 22-35.

19. Marcdante KJ, Kliegman RM, Jenson $\mathrm{HB}$, \& Behrhman RE. Nelson IImu Kesehatan Anak Esensial. Singapore: Elsevier. 2011; 339-449.

20. Sugiono LT, Barlianto W, Olivianto E, Kusuma HMSC \& Nurdiana. Pengaruh Pemberian Probiotik dan Nigella sativa sebagai Ajuvan Immunoterapi House Dust Mite terhadap Skor Asthma Control Test, Jumlah sel $\mathrm{CD} 4^{+} \mathrm{IL}-4^{+}$dan Kadar IgE pada Anak Asma Ringan. IOSR journals. 2013; 7:32-39. 